\title{
Protection by Carnosine and Homocarnosine against L-DOPA-Fe(III)-Mediated DNA Cleavage
}

\author{
Jung Hoon Kang \\ Department of Genetic Engineering, Cheongju University, Cheongju 360-764, Korea. *E-mail: jhkang@chongju.ac.kr \\ Received April 25, 2005
}

\begin{abstract}
It has been proposed that oxidation of L-3,4-dihydroxyphenylalanine (DOPA) may contribute to the pathogenesis of neurodegenerative disease. In this study, L-DOPA-Fe(III)-mediated DNA cleavage and the protection by carnosine and homocarnosine against this reaction were investigated. When plasmid DNA was incubated with L-DOPA in the presence of Fe(III), DNA strand was cleaved. Radical scavengers and catalase significantly inhibited the DNA breakage. These results suggest that $\mathrm{H}_{2} \mathrm{O}_{2}$ may be generated from the oxidation of DOPA and then $\mathrm{Fe}^{3+}$ likely participates in a Fenton's type reaction to produce hydroxyl radicals, which may cause DNA cleavage. Carnosine and homocarnosine have been proposed to act as anti-oxidants in vivo. The protective effects of carnosine and homocarnosine against L-DOPA-Fe(III)-mediated DNA cleavage have been studied. Carnosine and homocarnosine significantly inhibited DNA cleavage. These compounds also inhibited the production of hydroxyl radicals in L-DOPA $/ \mathrm{Fe}^{3+}$ system. The results suggest that carnosine and homocarnosine act as hydroxyl radical scavenger to protect DNA cleavage. It is proposed that carnosine and homocarnosine might be explored as potential therapeutic agents for pathologies that involve damage of DNA by oxidation of DOPA.
\end{abstract}

Key Words : L-DOPA, DNA cleavage, Hydroxyl radical, Carnosine

\section{Introduction}

3,4-Dihydroxyphenylalanine (DOPA) is an important precursor to several neurologically important catecholamines, such as the neurotransmitter dopamine, and the important hormones adrenaline and noradrenaline. Catechols are hydroquinones that may undergo oxidation to electrophilic semiquinones and quinines. Enzymatic oxidation of catechols followed by polymerization is a common form of pigmentation in animals. Also, protein-protein crosslinking by enzymatically oxidized catechols is a known mechanism of post-translational modification that occurs widely in nature. ${ }^{1}$ DOPA and dopamine can oxidize in vitro to generate semiquinones, $\mathrm{O}_{2}^{-\cdot}$ and $\mathrm{H}_{2} \mathrm{O}_{2},{ }^{2}$ a process greatly facilitated by the presence of transition-metal ions. In the case of iron and copper, $\mathrm{OH}$ will also be generated by Fenton reaction. ${ }^{3,4} \mathrm{OH}$ is the most powerful oxidizing species among several reactive oxygen radicals, and is able to oxidize most macromolecules like DNA, protein, lipid and carbohydrate. Recently, it has been reported that the modification and inactivation of human copper transport protein, ceruloplasmin, was induced by oxidized DOPA. ${ }^{5}$ The cause of the selective degeneration of neurons in brain of neurodegenerative disorders remains unknown; however, it has been well documented that an excessive production of free radicals during many oxidation reactions may account for the cytotoxicity in neurodegenerative disorders.

Carnosine ( $\beta$-alanyl-L-histidine) and related compounds such as anserine ( $\beta$-alanyl-1-methyl-L-histidine) and homocarnosine ( $\gamma$-amino-butyryl-L-histidine) are present in several mammalian tissues, including skeletal muscle and brain at high concentrations (up to $20 \mathrm{mM}$ in humans). ${ }^{6,7}$
Carnosine and anserine have been shown to be efficient copper-chelating agents, and it has been suggested that they may play a role in copper metabolism in vivo. ${ }^{8}$ Carnosine also protects rabbit heart from reperfusion injury after ischemia. ${ }^{9}$ Many biochemical studies have suggested that carnosine possesses antioxidant and free radical-scavenging function which may partly explain it apparent homeostatic function. ${ }^{10-12}$

In the present study, the protective effects of carnosine and homocarnosine on L-DOPA-Fe(III)-mediated DNA cleavage was investigated. Carnosine and homocarnosine significantly inhibited L-DOPA-Fe(III)-mediated DNA cleavage. In addition, it was found that carnosine and homocarnosine inhibited the generation of hydroxyl radicals in the reaction of L-DOPA and Fe(III).

\section{Materials and Methods}

Materials. L-3,4-dihydroxyphenylalanine (DOPA), catalase from bovine liver, sodium azide, mannitol, 2-deoxy-Dribose, and thiobarbituric acid were purchased from Sigma (St. Louis, USA). Chelex 100 resin was purchased from BioRad (Hercules, USA). All solutions were treated with Chelex 100 to remove traces of transition metal ions. pUC 19 plasmid DNA was purified from $E$. coli cultures by using Qiagen Plasmid Midi Kit (Santa Clarita, USA).

Analysis of DNA strand breaks. The pUC 19 plasmid DNA $(1 \mu \mathrm{g})$ in $10 \mathrm{mM}$ potassium phosphate buffer at $\mathrm{pH} 7.4$ was incubated for $2 \mathrm{~h}$ at $37{ }^{\circ} \mathrm{C}$ with DOPA and $\mathrm{FeCl}_{3}$. The reaction was stopped by freezing at $-80{ }^{\circ} \mathrm{C}$. Four $\mathrm{mL}$ of loading buffer $(0.25 \%$ bromophenol blue, $40 \%$ sucrose $)$ was added and samples were analyzed by electrophoresis in 
$0.8 \%$ agarose in TBE buffer $(90 \mathrm{mM}$ Tris, $90 \mathrm{mM}$ boric acid, 2 mM EDTA, pH 8.0). ${ }^{13}$ The gel was stained with ethidium bromide, photographed.

Measurement of hydroxyl radical. Detection of hydroxyl radicals was determined by measuring thiobarbituric acid reactive 2-deoxy-D-ribose oxidation products. ${ }^{14}$ Reaction mixtures contained DOPA and $\mathrm{FeCl}_{3}$. Mixtures were incubated at $37{ }^{\circ} \mathrm{C}$ for $2 \mathrm{~h}$. The degradation of 2-deoxy-Dribose was measured by adding $200 \mu \mathrm{L}$ of PBS, $200 \mu \mathrm{L}$ of $2.8 \%(\mathrm{w} / \mathrm{v})$ trichloroacetic acid, $200 \mu \mathrm{L}$ of $1 \%(\mathrm{w} / \mathrm{v})$ thiobarbituric acid, followed by heating at $100{ }^{\circ} \mathrm{C}$ for 10 min. After cooling, the absorbance at $532 \mathrm{~nm}$ was measured by a uv/vis spectrophotometer (Shimadzu, UV-1601).

Replicates. Unless otherwise indicated, each result described in this paper is representative of at least three separate experiments

\section{Results}

Untreated plasmid DNA showed a major band corresponding to the supercoiled form (form I) (Figure 1, lane 1). Plasmid DNA remained nearly intact after incubation with $100 \mu \mathrm{M}$ DOPA or $100 \mu \mathrm{M} \mathrm{FeCl}_{3}$ (Figure 1, lane 2 and 3). However, incubation of DNA with DOPA and $\mathrm{FeCl}_{3}$ induced DNA strand breakage as shown by the decrease in the amount of form I molecules and concomitant increase in nicked circular form (form II) (Figure 1, lane 4). The effect of the concentrations of DOPA on the production of DNA strand breaks was studied. In the presence of $\mathrm{FeCl}_{3}$, DNA strand breaks became apparent at $10 \mu \mathrm{M}$ DOPA, the cleavage was increased up to $70 \mu \mathrm{M}$ DOPA (Figure 2). Hydroxyl radical scavengers, azide and mannitol inhibited

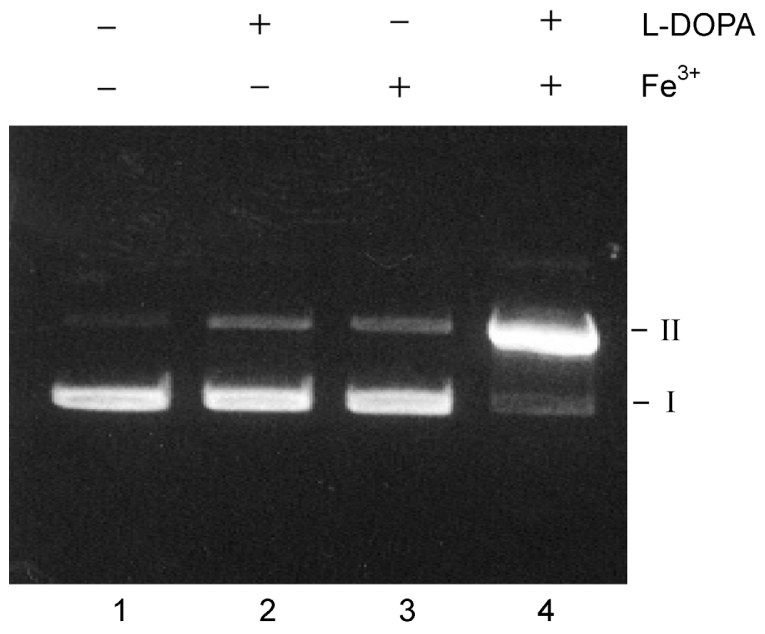

Figure 1. DNA cleavage induced by L-DOPA and Fe(III). pUC 19 DNA $(1 \mu \mathrm{g})$ was incubated in $10 \mathrm{mM}$ phosphate buffer $(\mathrm{pH} 7.4)$ at $37{ }^{\circ} \mathrm{C}$ for $2 \mathrm{~h}$ under various conditions. Lane 1, pUC 19 DNA control; lane 2, DNA $+100 \mu \mathrm{M}$ DOPA; lane 3, DNA $+100 \mu \mathrm{M}$ $\mathrm{FeCl}_{3}$; lane 4 , DNA $+100 \mu \mathrm{M}$ DOPA $+100 \mu \mathrm{M} \mathrm{FeCl}$. The reactions were stopped by freezing at $-80{ }^{\circ} \mathrm{C}$. Loading buffer was added to the samples and analyzed by electrophoresis on $0.8 \%$ agarose gel. I and II indicate the positions of the supercoiled and nicked circular DNA plasmid forms, respectively.
DNA strand breaks by the DOPA/Fe(III) system (Figure 3, lane 3 and 4). The results suggested that hydroxyl radicals also might participate in DNA strand breakage. Catalase also inhibited DNA strand breaks by the DOPA/Fe(III) system (Figure 3, lane 5). This implies that DNA strand breakage might be induced by hydroxyl radicals through the reaction of $\mathrm{Fe}^{3+}$ with $\mathrm{H}_{2} \mathrm{O}_{2}$.

Carnosine and related compounds are reported to be the active free radical scavenger. ${ }^{10,15,16}$ Effects of carnosine and homocarnosine on L-DOPA-Fe(III)-mediated DNA cleavage were investigated. These compounds showed a concentrationdependent inhibition of DNA cleavage induced by DOPA/

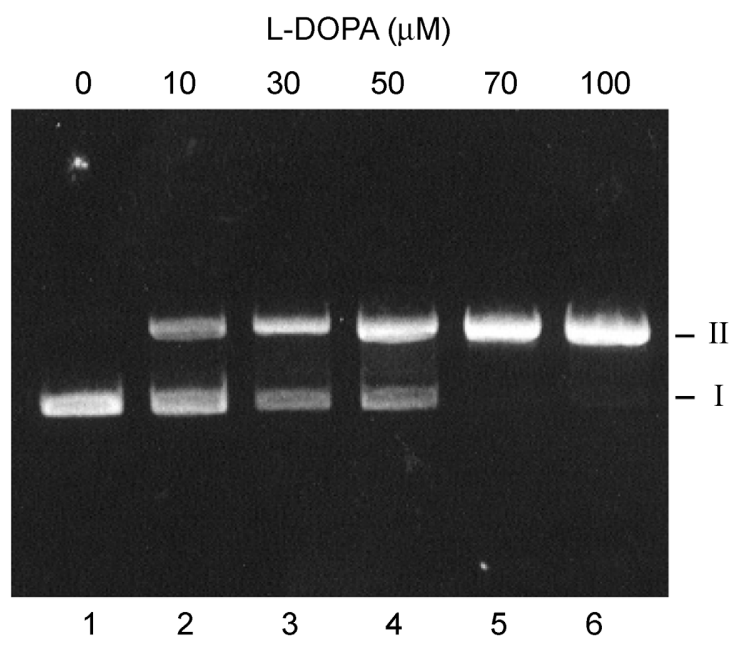

Figure 2. The effect of L-DOPA concentrations on the production of DNA strand breaks. DNA was incubated with the following: lane 1, DNA alone; lane 2, $10 \mu \mathrm{M}$ DOPA + $100 \mu \mathrm{M} \mathrm{FeCl}_{3}$; lane 3, $30 \mu \mathrm{M}$ DOPA + $100 \mu \mathrm{M} \mathrm{FeCl}_{3}$; lane $4,50 \mu \mathrm{M}$ DOPA $+100 \mu \mathrm{M}$ $\mathrm{FeCl}_{3}$; lane 5, $70 \mu \mathrm{M}$ DOPA $+100 \mu \mathrm{M} \mathrm{FeCl}_{3}$; lane 6, $100 \mu \mathrm{M}$ $\mathrm{DOPA}+100 \mu \mathrm{M} \mathrm{FeCl}_{3}$

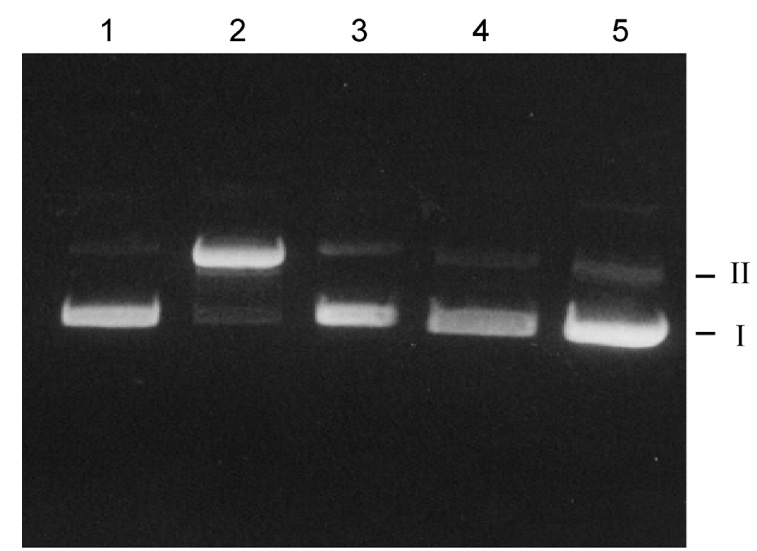

Figure 3. Effect of radical scavengers and catalase on DNA strand breakage. DNA was incubated with $100 \mu \mathrm{M}$ DOPA $+100 \mu \mathrm{M}$ $\mathrm{FeCl}_{3}$ in the presence of effectors. Lane 1, DNA alone; lane 2, no addition of effectors; lane 3,200 mM azide; lane 4, $200 \mathrm{mM}$ mannitol; lane 5 , catalase $(2 \mathrm{mg} / \mathrm{mL})$. The reactions were stopped by freezing at $-80{ }^{\circ} \mathrm{C}$. The samples were analyzed by electrophoresis on $0.8 \%$ agarose gel. I and II indicate the positions of the supercoiled and nicked circular DNA plasmid forms, respectively. 
(A)

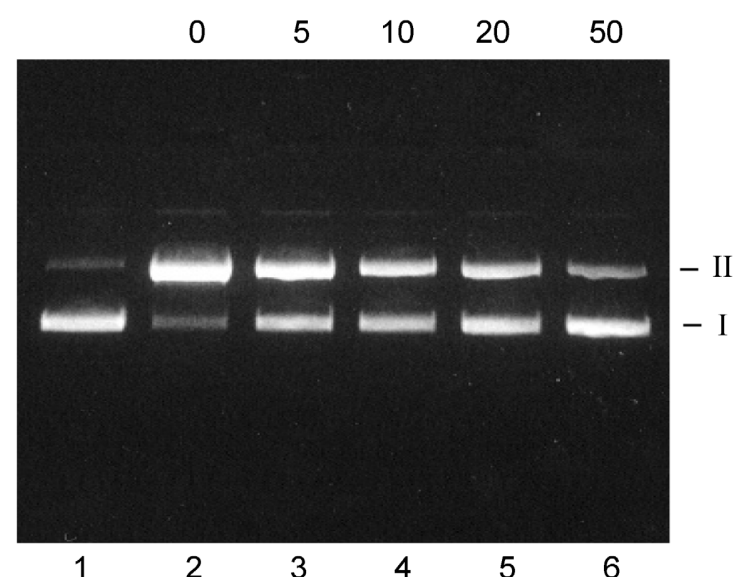

(B) Homocarnosine (mM)

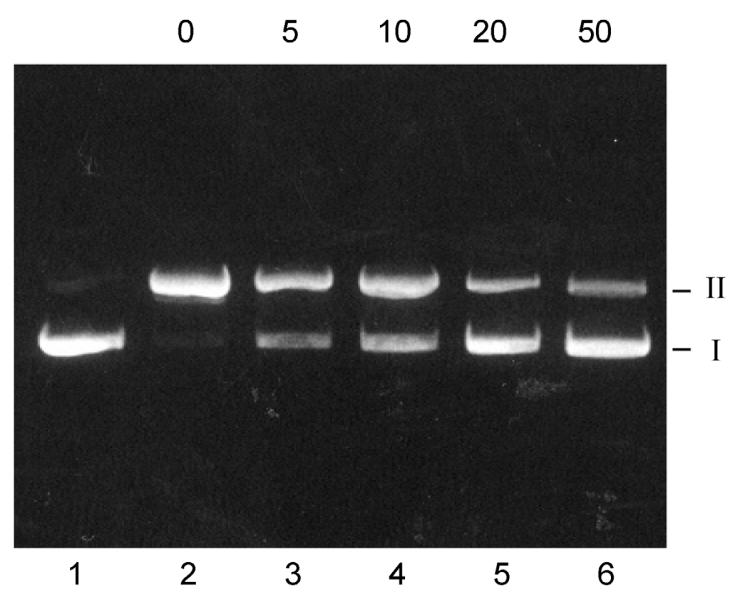

Figure 4. Effect of carnosine and homocarnosine on DNA cleavage. Control reaction mixture containing DNA $(1 \mu \mathrm{g}), 100$ $\mu \mathrm{M}$ DOPA and $100 \mathrm{mM} \mathrm{FeCl}_{3}$ in $10 \mathrm{mM}$ potassium phosphate buffer ( $\mathrm{pH}$ 7.4). Various concentrations of carnosine and homocarnosine were added into the control reaction mixture. Reaction mixtures were incubated at $37^{\circ} \mathrm{C}$ for $2 \mathrm{~h}$ and an aliquot was analyzed by agarose gel electrophoresis. (A) Lane 1, DNA control; lane 2, incubated with $100 \mu \mathrm{M}$ DOPA and $100 \mu \mathrm{M} \mathrm{FeCl}_{3}$; lane 3 , lane 2 plus $5 \mathrm{mM}$ carnosine; lane 4 , lane 2 plus $10 \mathrm{mM}$ carnosine; lane 5 , lane 2 plus $20 \mathrm{mM}$ carnosine; lane 6 , lane 2 plus $50 \mathrm{mM}$ carnoisne. (B) Lane 1, DNA control; lane 2, incubated with $100 \mu \mathrm{M}$ DOPA and $100 \mu \mathrm{M} \mathrm{FeCl}$; lane 3 , lane 2 plus $5 \mathrm{mM}$ homocarnosine; lane 4 , lane 2 plus $10 \mathrm{mM}$ homocarnosine; lane 5 , lane 2 plus $20 \mathrm{mM}$ homocarnosine; lane 6 , lane 2 plus $50 \mathrm{mM}$ homocarnoisne.

Fe(III) (Figure 4, A and B). Figure 5 shows the effect of increasing concentrations of DOPA on the formation of hydroxyl radicals in the presence and absence of carnosine and homocarnosine. The generation of hydroxyl radicals in $\mathrm{DOPA} / \mathrm{Fe}^{3+}$ system was measured with thiobarbituric acidreactive substance (TBARS). It was seen that the rate of formation of TBARS was considerably reduced in the presence of carnosine and homocarnosine. The results indicate that carnosine and related compounds may protect the oxidative damage to DNA through a mechanism of hydroxyl radical-scavenging.

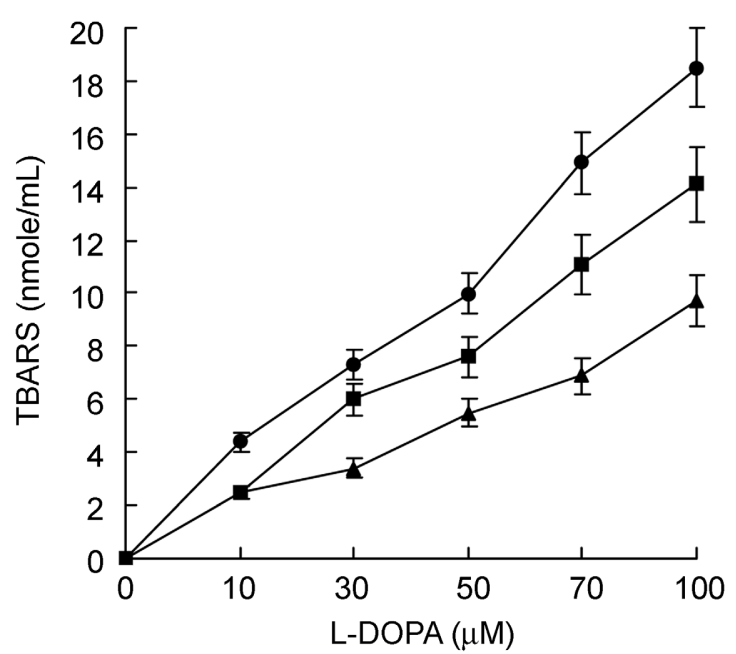

Figure 5. Effects of carnosine and homocarnosine on hydroxyl radical generation by the L-DOPA-Fe(III) system as a function of L-DOPA concentration. The reaction mixtures contained $10 \mathrm{mM} 2-$ deoxy-D-ribose and various concentration of L-DOPA ( $\bullet$ ) in the presence of $100 \mu \mathrm{M} \mathrm{FeCl}_{3}$ without and with $20 \mathrm{mM}$ carnosine ( $\Delta$ ) or $20 \mathrm{mM}$ homocarnosine ( $\boldsymbol{\square})$. Reaction mixtures were incubated at $37{ }^{\circ} \mathrm{C}$ for $2 \mathrm{~h}$. The degradation of 2-deoxy-D-ribose was measured by adding $200 \mu \mathrm{L}$ of PBS, $200 \mu \mathrm{L}$ of $2.8 \%(\mathrm{w} / \mathrm{v})$ trichloroacetic acid, $200 \mu \mathrm{L}$ of $1 \%(\mathrm{w} / \mathrm{v})$ thiobarbituric acid, followed by heating at $100{ }^{\circ} \mathrm{C}$ for $10 \mathrm{~min}$. After cooling, the absorbance at $532 \mathrm{~nm}$ was measured. Data represent the means \pm S.D. $(n=4-5)$.

\section{Discussion}

In the present study, the protective effect of carnosine and homocarnosine in DOPA/Fe(III)-mediated DNA cleavage was investigated. The toxicity of catechol may be augmented by its free radical-generating function in neurodegenerative disorder. Since the level of free radicals was reported to be increase in Parkinson's disease (PD) patients, ${ }^{17,18}$ the oxidative damage of DNA might have pathological significance. Present result showed that cleavage of DNA was induced by the oxidation of DOPA in the presence of $\mathrm{FeCl}_{3}$. DOPA and dopamine can oxidize in vitro to generate semiquinones, $\mathrm{O}_{2}^{-}$and $\mathrm{H}_{2} \mathrm{O}_{2},{ }^{2}$ a process greatly facilitated by the presence of transition-metal ions. In the case of iron and copper, $\mathrm{OH}$ will also be generated by Fenton reaction.,4 Because iron is known to abundantly exist in the substantia nigra and its increase in PD has been consistently reported, ${ }^{19,20}$ it was hypothesized that aberrant iron metabolism might be involved in the pathogenesis of PD. In this study, it was found that the DOPA/Fe(III)-mediated DNA cleavage was inhibited by hydroxyl radical scavenger and catalase. These results indicate that hydroxyl radicals and hydrogen peroxide may be involved in the DOPA/ $\mathrm{Fe}$ (III)-mediated DNA cleavage.

Carnosine has been shown to delay senescence ${ }^{21}$ and decreases production of oxidized $\mathrm{DNA}^{22}$ in cultured human fibroblasts. It has been reported that the increased antioxidant activity of carnosine and related compounds when copper was used to promote oxidation was likely due 
to their ability to chelate and inactivate copper. ${ }^{6,16}$ In this study, carnosine and homocarnosine significantly inhibited DNA cleavage by DOPA/Fe(III) system. Carnosine has not been found to chelate iron in a manner that reduces its prooxidant activity. ${ }^{16}$ It has been reported that carnosine and related compounds quench $50-95 \%$ of hydroxyl radicals produced in the Fenton reaction. ${ }^{23}$ Therefore, it was suggested that the ability of carnosine and homocarnosine to inhibit iron-promoted oxidation was likely due to free radical scavenging activity.

In conclusion, the present results suggest that DNA cleavage was induced by the oxidation of DOPA, involving $\cdot \mathrm{OH}$ generation from $\mathrm{H}_{2} \mathrm{O}_{2}$. DNA damage by the DOPA and $\mathrm{Fe}$ (III) system might therefore be associated with the pathogenesis of neurodegenerative disorders. Although our results were obtained from in vitro experiments, carnosine and homocarnosine compounds may play an important role in the maintenance of the antioxidant system.

\section{References}

1. Waite, J. H. Comp. Biochem. Physiol. B. 1990, 97, 19-29.

2. Pileblad, E.; Slivka, A.; Bratvold, D.; Cohen, G. Arch. Biochem. Biophys. 1988, 263, 447-452.

3. Halliwell, B.; Gutteridge, J. M. C. FEBS Lett. 1992, 307, 108-112.

4. Sutton, H. C.; Winterbourn, C. C. Free Radic. Biol. Med. 1989, 6, 53-60.

5. Kang, J. H. Bull. Korean Chem. Soc. 2004, 25, 625-628.
6. Kohen, R.; Yamamoto, Y.; Cundy, K. C.; Ames, B. N. Proc. Natl. Acad. Sci. USA 1988, 85, 3175-3179.

7. O'Dowd, J. J.; Robins, D. J.; Miller, D. J. Biochem. Biophys. Acta 1988, 967, 241-249.

8. Brown, C. E. J. Theor. Biol. 1981, 88, 296-299.

9. Gercken, G.; Bischoff, H.; Trotz, M. Arzneimittel-Forschung 1980, 30, 2140-2143.

10. Aruoma, O. I.; Laughton, M. J.; Halliwell, B. Biochem. J. 1989, 264, 863-869.

11. Dahl, T. A.; Midden, W. R.; Hartman, P. E. Photochem. Photobiol. 1988, 47, 357-362.

12. Hartman, P. E.; Hartman, Z.; Ault, K. T. Photochem. Photobiol. 1990, 51, 59-66.

13. Kang, J. H. Bull. Korean Chem. Soc. 2005, 26, 178-180.

14. Halliwell, B.; Gutteridge, J. M. C. FEBS Lett. 1981, 128, 347352.

15. Hipkiss, A. R.; Brownson, C. Cell Mol. Life Sci. 2000, 57, 747753.

16. Decker, E. A.; Crum, A. D.; Calvert, J. T. J. Agric. Food Chem. 1992, 40, 756-759.

17. Ilic, T.; Jovanovic, M.; Jovicic A.; Tomovic, M. Vojnosanit. Pregl. 1998, 55, 463-468.

18. Ilic, T.; Jovanovic, M.; Jovicic, A.; Tomovic, M. Funct. Neurol. 1999, 14, 141-147.

19. Halliwell, B. Acta Neurol. Scand. Suppl. 1989, 126, 23-33.

20. Youdim, M. B.; Ben-Shachar, D.; Riederer, P. Acta Neurol. Scand. Suppl. 1989, 126, 47-54.

21. McFarland, G. A.; Holliday, R. Exp. Cell Res. 1994, 212, 167-175.

22. Kantha, S. S.; Wada, S.; Tanaka, H.; Takeuchi, M.; Watabe, S.; Ochi, H. Biochem. Biophys. Res. Comm. 1996, 223, 278-282.

23. Chan, W. K. M.; Decker, E. A.; Lee, J. B.; Butterfield, D. A. J. Agric. Food Chem. 1994, 42, 1407-1410. 